\title{
o êxodo da casa do sogro é prenúncio do êxodo do país opressor (Ex 4,19-23)
}

\author{
The exodus of the father in low house \\ is foretaste of exodus of the oppressor \\ country (Ex 4,19-23)
}

Leonardo Agostini Fernandes*

Resumo: 0 presente artigo trata de um breve episódio no qual se narra uma experiência prévia do êxodo do Egito e das dificuldades que o mediador Moisés vai encontrar para realizar a sua missão. A presente análise faz uso de uma abordagem mais sincrônica, privilegia e explora a dimensão literária, na qual é possível perceber, com mais clareza, tanto o sentido literal como o sentido pleno encerrados no texto. Evita-se cair na tentação que levou muitos estudiosos no passado a se preocupar muito mais com o processo e as etapas de formação do que com o resultado final. A razão para essa opção advém da percepção de que as tensões encontradas no texto não testemunham somente a história do desenvolvimento, mas também o forte desejo de criar um relato unificado, a fim de que a mensagem fosse mais facilmente perceptível ao ouvinte-leitor:

* Doutor em Teologia Bíblica pela Pontifícia Universidade Gregoriana (Roma), diretor e professor de Sagrada Escritura na Pontifícia Universidade Católica do Rio, sócio da ABI, da ABIB, da SOTER, e membro do grupo de Pesquisa da CNPq - Tradução e Interpretação do Antigo Testamento: TIAT, Rio de Janeiro, RJ - Brasil, e-mail: laf2007@puc-rio.br 
uma experiência e uma expressão de fé em um Deus providente e previdente.

Palavras-chave: Antigo Testamento; Êxodo; Libertação; Mediação; Opressão.

Abstract: This article studies a brief episode about the previous experience of the exodus from the Egypt and the difficulties that Moses, the mediator, will meet to realize his mission. This analyses makes use more a synchronic approach, to emphasize and to explore the literary dimension, because in this approach is possible to obtain, with more clearness, the literal sense and the total sense in the text. In this article avert to fell in the temptation that conduce many scholarships in the past went preoccupied much more with the process and the stages than the final considerations. The reason for this choice stems from the perceptions that the tensions found in the text don't give only evidence the development the history, but also a strong desire to create a unified narrative, for the message would be more readily for the interlocutor: an experience and expression for the faith in a liberator God.

Keywords: Old Testament; Exodus; Liberation; Mediation; Oppression.

\section{Introdução}

Um texto bíblico possui um grande número de informações a serem percebidas e pesquisadas: pessoas, locais, circunstâncias, eventos, situações, relações, estrutura, estratégias comunicativas, etc. Um ou vários autores são os responsáveis pelos textos. Estes almejam e demandam a atenção do ouvinte-leitor. Em geral, pode-se pensar nessas informações a partir das noções básicas do processo comunicativo: um emissor, uma mensagem e um receptor, que deve ser capaz de receber, guardar e transmitir, com fidelidade, o conteúdo da mensagem. O que se diz, no presente, fundamentado, por exemplo, em uma promessa feita no passado cria a abertura para o futuro. 
Para o ouvinte-leitor contemporâneo, porém, essas informações não são suficientes para se obter uma correta compreensão e vislumbrar o alcance bíblico-teológico do que se está lendo e estudando. ${ }^{1}$ Quem deseja se aproximar corretamente dos textos bíblicos, pela fé e pela razão, precisa munir-se de ferramentas adequadas para adentrar nesse vasto e inesgotável campo de estudo que demanda um profundo conhecimento, não somente dos métodos a serem aplicados, mas também da cultura judaico-cristã e de suas relações. ${ }^{2}$

Nos níveis, pessoal e social, sempre existiram problemas de ordem relacional, cultural e religioso, que implicavam e se verificavam, principalmente, nos aspectos político e econômico. Acrescente-se a isso um fator essencial: a luta contra as enfermidades, doenças e, em particular, todo o esforço para afastar a sombra da morte. A pessoa do mediador religioso torna-se imprescindível nesse contexto, pois as diferenças sociais demandavam por soluções que ultrapassavam as capacidades e as forças humanas para que se restabelecesse a ordem psíquica, física e social. Neste sentido, a religião jogava e ainda joga um papel preponderante e, em muitos casos, decisivo em certas questões. Ex 4,19-23 permite perceber tudo isso.

\section{Contexto}

\subsection{Contextualização do episódio}

O ouvinte-leitor atento poderia questionar se estes versículos não parecem ignorar, quase que por completo, toda a tratativa que aconteceu no contexto precedente (Ex 3,1-4,18). Há tensões, mas estas não chegam a destoar do conjunto da narrativa. Percebe-se que a explícita ordem de YHWH, quanto à partida de Moisés, introduz

1 Cf. SILVA, L. H. E., “O Sentido Teológico do Texto Bíblico: releitura e horizontes da intervenção de Bento XVI durante o Sínodo sobre a Palavra na Vida e na Missão da Igreja”. In: Horizonte Teológico, v. 10, n. 18 (jul./dez. 2010) pp. 9-27

2 Pont. Com. Bíbl, 2002. 
novos elementos, mas com base nos acontecimentos precedentes. O que acontece é uma transição entre o longo episódio do chamado de Moisés para uma missão libertadora $(\operatorname{Ex~3,10)~e~o~início~da~sua~}$ execução com a partida de Madiã, após receber a aprovação de Jetro, seu sogro (Ex 4,18).

A saída de Moisés de Madiã marcou, portanto, o término da sua vida e atividades nessa localidade, pois a ela nunca mais retornou. É o fim de uma etapa da vida de Moisés que marca o início da sua atividade como libertador dos filhos de Israel, em uma aventura de vida e morte. ${ }^{3}$ A narrativa quer colocar em evidência a complementaridade entre ação divina e ação humana. YHWH e Moisés são os agentes coniventes contra o Faraó, sua terra e seu povo. A notícia da libertação vem de fora, mas deve se tornar o desejo dos que clamaram em sua aflição. Nesse sentido, por meio de Moisés, YHWH medirá forças com o Faraó e o vencerá.

A partida aconteceu, porém, em Madiã. Moisés não regressou na direção do Egito desde o Horeb, porque este se tornará o ponto de encontro de Aarão com Moisés (Ex 4,27). Dá-se uma inversão que resgata a notícia contida em Ex 2,15. Assim como o Egito fora o ponto de partida de Moisés e Madiã, o seu ponto de chegada, agora Madiã é o ponto de partida de Moisés e o Egito, o seu ponto de chegada. Neste sentido, Ex 4,19-23 serve de ponte, no presente da narrativa, entre o passado e o futuro de Moisés.

Quanto ao passado, serve para informar Moisés de que o Egito não oferece mais um risco de morte para ele. A notícia da morte dos que procuraram matar Moisés recupera a notícia dada em Ex 2,22. Essa revelação serve como elemento que reforça o sentido do regresso de Moisés para o Egito. Pode-se dizer que a causa do êxodo de Moisés perdeu a sua força pela morte do que lhe havia sentenciado de morte. Serve, também, como garantia de segurança para Jetro,

COATS, G. W., Exodus 1-18 [vol. IIA]. Michigan/Cambridge: Grand Rapids, 1999, p. 44. 
que não se opusera à partida do genro que decidiu levar consigo a sua filha e seus netos. Percebe-se a força da paz (šalom) desejada pelo sogro ao genro. Por este desejo se estabelece um novo vínculo de Moisés com Jetro para além do vínculo de sangue.

Quanto ao futuro, antecipa o significado e as dificuldades da missão confiada a Moisés. A saída dos filhos de Israel do Egito não será como a sua saída da casa de Jetro. Os sinais operados diante do Faraó não serão capazes de convencê-lo a deixar partir os filhos de Israel, cujo objetivo foi o de realizar, no deserto, um sacrifício a YHWH. Com isso, anunciava-se ao Faraó o nome da divindade à qual os filhos de Israel pertencem. A razão dessa pertença recai sobre a afirmação de que eles são o "filho primogênito" de YHWH, que, como pai, reclama a liberdade do próprio filho. Por causa da obstinação do Faraó, são antecipados os motivos que levarão YHWH a ferir de morte o primogênito do Faraó.

\subsection{Delimitação do texto}

Com relação ao texto precedente (Ex 4,10-17), notam-se várias mudanças. Em primeiro lugar, a mudança de local: Moisés não está mais no Horeb, mas na tenda de Jetro em Madiã. Em segundo lugar, a nova fala de YHWH é uma ordem e não discursos para convencer Moisés a regressar para o Egito. Em terceiro lugar, evidencia-se que Moisés, pela experiência que fez no Horeb, passou a ouvir a voz de YHWH em qualquer lugar, insistindo com a sua vocação e missão. Em quarto lugar, a ordem de YHWH evidencia que o pedido de Moisés a Jetro e sua concessão servem para demonstrar que ele não agiu como o Faraó agirá diante do que Moisés tem a falar e os sinais quem tem a realizar. Jetro, ao contrário do Faraó, deixou Moisés partir com a sua família para cumprir a sua missão (Ex 4,18). O Faraó fará de tudo para não deixar partir Moisés e o seu povo.

Além disso, o conteúdo da fala de YHWH a Moisés parece destoar do episódio anterior. A revelação da morte do Faraó, já sabida 
pelo ouvinte-leitor desde Ex 2,23, teria sido um forte argumento para convencer Moisés se tivesse sido dada antes. Fica claro, por um lado, que esta nova ordem serve, então, para reiterar e reforçar o sentido do regresso de Moisés ao Egito, assegurando que é vontade divina; por outro lado, serve não somente para completar a notícia dada em Ex 3,19, mas para introduzir duas novidades: a resistência do Faraó foi provocada pelo próprio YHWH e a declaração de que Israel é o seu filho primogênito confronta-se com a notícia de que o do filho primogênito do Faraó morrerá devido à sua obstinação. Enquanto YHWH salvará o seu primogênito, o Faraó fará morrer o seu primogênito.

Com relação ao texto subsequente (Ex 4,24-26), apesar desse episódio fazer parte do relato sobre o regresso de Moisés e de sua família ao Egito, percebe-se que se está diante de um novo episódio. O protagonismo das ações mudou e passou para Séfora e não estão mais nas mãos de Moisés que vinha tomando iniciativas, obedecendo à ordem de YHWH. Entre os dois episódios, YHWH continua como protagonista e como alguém que não somente anuncia a morte do opositor, mas pode ser, também, um opositor capaz de ferir de morte Moisés e sua família. Este dado serve para confirmar a ameaça contida em Ex 4,23: YHWH é capaz de ferir de morte. Moisés experimenta, de forma antecipada, o que acontecerá com o Egito devido à obstinação do Faraó. Moisés, com isso, aprende que não deve se obstinar diante das ordens de YHWH, pois tal atitude é portadora de morte.

\section{Tradução}

${ }^{19} \mathrm{E}$ YHWH disse a Moisés em Madiã: “Anda, regressa $a o$ Egito, porque estão mortos todos os homens que buscavam a tua vida”. ${ }^{20}$ Moisés tomou a sua mulher e seus filhos e os fez montar sobre o asno e regressou na direção da terra do Egito. Moisés tomou ainda o bastão de Deus em sua mão. ${ }^{21}$ Então, disse YHWH a Moisés: “Ao 
regressar na direção do Egito, vê todos os prodígios que meto em tuas mãos e os farás diante do Faraó, mas eu farei resistente o coração dele e não deixará ir o meu povo". ${ }^{22}$ E dirás ao Faraó: “Assim disse YHWH: o meu filho primogênito é Israel. ${ }^{23}$ Por isso te disse: deixa ir o meu filho que me servirá; mas recusastes deixá-lo ir. Eis que farei perecer teu filho, o teu primogênito”.

\section{Estrutura e gênero literário}

O texto está estruturado segundo um esquema concêntrico simples. Estabelece-se a relação entre ordem (A - B - C) e execução (A' - B' - C'), com dados complementares. Pode-se admitir, também, uma relação entre causa $(A-B-C)$ e efeito (A' - B' - C'). Ação e reação colocam os personagens em movimento e em forte interação. As três falas de YHWH ritmam o nexo causal entre o passado, o presente e o futuro dos acontecimentos, de modo que um sumário histórico contextualiza uma revelação profética (“Assim disse YHWH”). A estrutura pode ser visualizada da seguinte maneira:

A: YHWH fala a Moisés em Madiã (v. 19a) + complementos (v. 19b)

A': Moisés obedece a YHWH (v. 20a) + complementos (v. 20b)

B: YHWH fala a Moisés (v. 21a) + complementos (v. 21b)

B’: Moisés deve obedecer a YHWH (v. 22a)

C: YHWH fala ao Faraó (v. 22b) + complementos (v. 23a)

C’: Faraó não obedece YHWH (v. 23b) + complementos (v. 23c)

Pode-se dizer que o episódio é aberto e fechado com uma notícia sobre a morte (vv. 19a.23c). Esta notícia permite recordar, além do decreto de morte para Moisés, depois da morte do egípcio (Ex 2,11-15), os inícios da vida de Moisés que nasceu em um contexto de morte decretada (Ex 1,15-22), sem que houvesse desobediência ao Egito da parte dos filhos de Israel. A morte decretada por YHWH para o primogênito do Faraó, ao contrário, está calcada na desobediência por parte do Faraó à ordem dada por YHWH (v. 23). 
O narrador introduziu o novo episódio e cedeu a fala a YHWH por três vezes: duas diretas (vv. 19.21) e uma indireta (v. 22). YHWH é o protagonista e o opositor do Faraó, que, por sua vez, será o opositor de YHWH na oposição que fará a Moisés e a Aarão.

Na primeira fala encontra-se uma nova ordem de YHWH a Moisés, acompanhada de uma revelação fundamental. Assim, Moisés, sem alguma reação oral ou hesitação, executa a ordem, fazendo-se acompanhar da sua família. Uma nova fala de YHWH a Moisés é introduzida pelo narrador. Esta nova fala contém orientações para Moisés, quanto ao que deve dizer - terceira fala de YHWH - e o que deve fazer diante do Faraó. Uma nova revelação, antecipando o futuro, é feita, pela qual YHWH justifica e dá as razões para as consequências que se seguirão ao ato de desobediência do Faraó. Com isso, lançam-se as bases para a obrigação do resgate dos primogênitos (Ex 11,1-10; 12,29-34; 13,1-10.11-16).

\section{Estrutura da narrativa}

A relação entre causa e efeito, ou ação e reação, permite a coesão da trama narrativa. À ação de YHWH (causa) segue-se a reação positiva de Moisés (efeito), que, por sua vez, deve se tornar a causa (ação de Moisés) diante do Faraó com sua reação negativa (efeito) que, por sua vez, causa um novo efeito (reação de YHWH) sobre o primogênito do Faraó. A nova situação de morte, pelo contexto, passa para as mãos de YHWH (causa), mas também é apresentada como sendo o efeito da desobediência do Faraó. A determinação de YHWH, de levar a termo a sua vontade, recebe uma explicação e o fio condutor torna-se evidente na narrativa.

Quanto ao tempo, o episódio não apresenta alguma marca temporal definida, mas está situado após o regresso de Moisés do monte Horeb, no momento em que YHWH deu uma nova ordem de partida a Moisés, que já se despedira de Jetro, acrescentando uma motivação que contém uma notícia do passado. A viagem de regresso 
de Moisés para o Egito acontece no presente da narrativa e termina com o anúncio futuro do que se dará no local de destino ao Faraó.

Quanto ao lugar, há duas referências definidas: Madiã é o ponto de partida e o Egito, com três citações explícitas, é o ponto de chegada. Deve-se acrescentar o trajeto a ser percorrido, isto é, uma etapa intermediária entre a saída de Madiã e a chegada ao Egito.

Quanto às personagens, que atuam neste episódio, elas podem ser classificadas de diretas e indiretas. YHWH, que ordena, e Moisés, que obedece, são as personagens diretas. O protagonismo de Moisés aparece submisso ao de YHWH. Séfora, os filhos de Moisés, o Faraó e o seu filho primogênito são as personagens indiretas. As duas primeiras são as personagens do ponto de partida; Faraó e o filho primogênito são as personagens no ponto de chegada. Moisés atua ao lado de todas elas que, por sua vez, atuarão também ao lado de Moisés. Séfora, procurando salvar, e o Faraó, procurando impedir a missão de Moisés. Ao lado dessas cinco personagens, que atuaram ao lado de Moisés, os homens que buscavam a sua morte também são personagens indiretas, mas já não podem fazer algum dano a ele: estão mortos. Além dessas, o povo de Israel, primogênito de YHWH, é a personagem alvo da sua ação libertadora das mãos do Faraó através das mãos de Moisés.

Quanto ao tema, sobressai a obediência de Moisés à ordem de partida e à missão a ser desenvolvida no Egito, anunciando a vontade de YHWH ao Faraó. Esta obediência é o ponto central e figura em primeiro plano na narrativa ao lado da insubmissão do Faraó à vontade libertadora de YHWH. O anúncio da morte do primogênito do Faraó serve de elemento antecipador da última praga sobre todo o Egito. Por este anúncio, completam-se as informações contidas em Ex 3,19-20. Nestes versículos, YHWH já havia dito a Moisés que, por suas intervenções portentosas, o Faraó seria obrigado a deixar partir os filhos de Israel do Egito. A argumentação da vida desejada para os filhos de Israel, pelo anúncio da morte do primogênito do 
Faraó, aumenta ainda mais a complexidade do tema da obediência que se exigirá ao longo de todo o livro do Êxodo.

Os estágios da narrativa, introdução, ação, complicação, clímax e desfecho, podem ser percebidos claramente. "E YHWH disse a Moisés em Madiã: ‘Anda, regressa ao Egito... a tua vida’”. (v. 19: introdução); "Moisés tomou... fez montar... e regressou... tomou... em sua mão. Então disse YHWH a Moisés... os farás diante do Faraó” (vv. 20-21: ação); "mas eu obstinarei o coração dele e não deixará ir o meu povo" (final do v. 21: complicação); "Assim disse YHWH: o meu filho primogênito é Israel” (v. 22: clímax); “Eis que farei perecer teu filho, o teu primogênito" (final do v. 23: desfecho).

\section{Comentários}

$4{ }^{19} \mathrm{E} Y H W H$ disse a Moisés em Madiã: "Anda, regressa ao Egito, porque estão mortos todos os homens que buscavam a tua vida".

A Septuaginta possui um texto maior que o Texto Massorético, porque, nela, o narrador antecipa uma informação antes de ceder a fala a YHWH: "E depois de muito tempo, o rei do Egito terminou os seus dias”. A ordem, que se segue, dada com ênfase a Moisés, fica alargada e enquadrada pela mesma informação. Além disso, poucos manuscritos hebraicos e o Pentateuco Samaritano possuem a partícula de direção (“regressa na direção do Egito"), o que deixa o texto mais correto (Nm 14,3). Se houve uma falha gramatical, está foi corrigida no Texto Massorético pelos dois versículos seguintes: “e regressou na direção da terra do Egito" e "para regressar na direção do Egito”. Com isso, a correção torna-se desnecessária no hebraico, pois a "falta" de informação anterior recebe solução posterior pelo próprio contexto.

Ex 4,19 possui uma estrutura parecida com Ex 4,18. Um sujeito (Jetro/YHWH) que fala ao mesmo interlocutor (Moisés) e se segue a mesma ordem (“vai”). Nesse sentido, a permissão de Jetro, que não se opôs à partida de seu genro, passa para o segundo plano e fica em 
evidência que Moisés não partiu por causa da bênção recebida do sogro, mas porque recebeu e obedeceu à ordem de YHWH. Nota-se, assim, a passagem de uma realidade antropológica para uma teológica. Esta passagem poderia não ter alguma relevância se a ordem de Jetro, “vai em paz!”, fosse interpretada como sendo um modo de dizer: "vai com Deus!".

Ao lado disso, fica também em segundo plano a atitude de Moisés. O seu regresso para o Egito não foi apenas a expressão do desejo de quem sentiu a necessidade de "recuperar" as suas origens étnicas, como tinha dito a Jetro para justificar a saída de sua tenda em Madiã, mas porque não foi capaz de resistir ao chamado que recebeu do Deus do seu pai, cujo nome ele "conhece”. Mais uma vez, acontece a passagem de uma realidade antropológica para uma teológica, de um desejo humano para a realização da vontade divina.

Moisés, após a experiência do Horeb, passou a ser o interlocutor de YHWH e a ser capaz de ouvir a sua voz também em Madiã. Isso atesta, por um lado, que existe certa continuidade no que diz respeito à missão recebida no Horeb, mas, por outro lado, atesta-se que existe uma ruptura, porque Moises nunca mais regressaria a Madiã, visto que foi para o Horeb que teve de conduzir os libertos do Egito (Ex 3,12).

YHWH, na última tratativa que aconteceu no monte Horeb, ficara irado com as insistentes reticências de Moisés para aderir à missão (Ex 4,13-17). Com isso, expectativas são criadas no ouvinte-leitor, porque Moisés, logo a seguir, deixou o monte Horeb sem dar uma pronta resposta a YHWH, isto é, se aderiria ou não ao chamado e à missão libertadora.

A revelação de que no Egito não havia mais perigo de morte para Moisés, porque já estavam mortos os seus inimigos, figura como um novo argumento para colocá-lo em movimento no caminho da obediência. Essa revelação, porém, cria um contraste com a fala de Moisés a Jetro, pois YHWH não disse que seus irmãos estavam 
vivos, mas que seus inimigos estavam mortos. É curioso o plural, “todos os homens”, revelando que o Faraó não fora o único a querer a morte de Moisés. A locução “todos os homens”, dentro do Pentateuco, se repetirá, somente, na queixa de YHWH contra os que, com exceção de Josué e Caleb, se revoltaram e não quiseram conquistar a terra (Nm 14,22). Esses morreram no deserto e não entraram na terra prometida.

$4{ }^{20}$ Moisés tomou a sua mulher e seus filhos e os fez montar sobre o asno e regressou na direção da terra do Egito. Moisés tomou ainda o bastão de Deus em sua mão.

Não se está diante de uma simples sequência de ações. Existe um dado relevante: Moisés, finalmente, aparece convencido e toma uma decisão: deve regressar ao Egito. Ao lado disso, uma dúvida surge e fica em suspense: Moisés conseguirá unir a si os anciãos de Israel e, juntos, conseguirão convencer o Faraó a deixar partir os filhos de Israel? Por certo, muitos elementos presentes em Ex 3,1-4,18 já fornecem a resposta. O Faraó, segundo as ações e previsões de YHWH, terá o coração endurecido e somente deixará partir os filhos de Israel quando for abatido na sua força varonil.

O fato de Moisés tomar sua esposa e seus filhos como acompanhantes no caminho de regresso rumo ao Egito cria certos problemas. Sem dúvida alguma, teria sido mais fácil, mais rápido e menos arriscado viajar sozinho do que na companhia de mulher e filhos. À parte dos problemas históricos ou que remontam a diferentes tradições sobre a mulher e os filhos de Moisés, uma pergunta surge: Por quais razões, Moisés não deixou a sua família, ao seguro, com seu sogro? O episódio seguinte desmentirá a certeza acima, mostrando a importância da presença da mulher e dos filhos. Até o presente momento da narrativa, sabe-se que Moisés tinha um filho (Ex 2,22), e o próprio incidente no caminho para o Egito faz pensar em um filho (Ex 4,25). A referência a dois filhos cria um problema e a mesma somente voltará, na narrativa, em Ex 18,2-6. ${ }^{4}$

4 Cf. FERnAndeS, L. A. - GREnZER, M., Exxodo 15,22-18,27. São Paulo: Paulinas, 2011, 129-131. 
Por certo, a cena é pitoresca e provocadora. Moisés manifestava a sua fé em YHWH, levando consigo a sua família, visto que lhe fora revelado que não mais corria risco de morte. Se essa foi a situação final e convincente, as razões que Moisés apresentou a Jetro fariam sentido, pois as condições dos filhos de Israel poderiam ter mudado, com a mudança do regente do Egito. Era preciso, apenas, constatar? Teria tido Moisés a intenção de regressar, após a sua missão, para Jetro? Não há indícios para se afirmar ou se negar tal possibilidade.

Entretanto, se houve uma mudança na sorte dos filhos de Israel, esta criaria novos problemas, pois a sua missão libertadora já não faria tanto sentido. O que Moisés viu no Egito desmentiu essa possibilidade? Em parte, é possível que sim, pois na primeira audiência com o Faraó a solicitação não foi por libertação total, mas foi um pedido de afastamento das atividades, isto é, uma ausência temporária para que YHWH fosse cultuado no deserto (Ex 5,1-5). Caso isso não acontecesse, os filhos de Israel é que seriam castigados com a peste e a espada. ${ }^{5}$ Algo estranho para uma missão libertadora.

A recusa do Faraó não é coerente com as razões iniciais: "Surgiu no Egito um novo rei que não tinha conhecido a José” (Ex 1,8), mas com as condições de trabalho, pois continuava sendo forçado e desumano. 0 termo que indica o trabalho árduo e mal remunerado ( $\left.s^{\mathrm{e}} \underline{b} \bar{a} l \hat{t} t\right)$, que recorre seis vezes (Ex 1,11; 2,11; 5,4-5; 6,6-7), confirma essa afirmação. 0 decreto de morte dos primogênitos, devido à explosão demográfica, parece ter deixado de existir, levando-se em conta a afirmação do Faraó: "eis que, agora, o povo da terra está numeroso" (Ex 5,5). ${ }^{6}$ Em outras palavras: os filhos de Israel voltaram

Não há indícios que levem a pensar que o anúncio de castigo se referisse ao Faraó e ao Egito. Caso a peste e a espada acontecessem aos filhos de Israel, isto representaria um novo decréscimo na mão de obra e o Egito seria prejudicado. Jr 42,17 contém uma notícia de morte decretada por YHWH para todos os homens que regressassem ao Egito. Com isso, o Egito passa de lugar de vida ao lugar de morte para o antigo Israel.

6 O Pentateuco Samaritano corrigiu o texto "são mais numerosos que o povo do país". Isto é, os filhos de Israel continuaram aumentando em número e passaram, de novo, o número dos egípcios. 
a ser fecundos e estão empregados. Por que, então, interromper o novo ritmo das coisas?

A presença do asno não figura como animal de carga, mas de transporte da mulher e dos filhos. ${ }^{7}$ Moisés é quem realiza a ação, mas não se fez alguma referência quanto às provisões para a viagem. Um dado que só pode ser admitido como pressuposto. Ex 4,20 é a primeira referência a esse animal que continuará recorrente em todo o livro do Êxodo como um bem apreciado.

Se porventura não houvesse a referência a Jetro e a Madiã em Ex 4,18 e se passasse imediatamente para Ex 4,19, sem a alusão a Madiã, seria possível dizer que a ordem de partida aconteceu ainda no Horeb. A razão para essa afirmação advém, igualmente, da última fala de YHWH a Moisés: "E toma em tua mão este bastão, porque farás com ele os sinais”; o que ocorreu, em sinal de obediência, em Ex 4,20b.

A segurança que Moisés espera ter no regresso para o Egito está em suas mãos: é o bastão de Deus. Moisés já sabe o que ele representa e o que é capaz de fazer com ele. A sua confiança, porém, deve estar não no bastão, mas em YHWH. O bastão, que esteve nas mãos de Moisés e servia como instrumento de proteção para si mesmo e para o rebanho, passou a ter uma nova função.

$4{ }^{21}$ Então disse YHWH a Moisés: "Ao regressar na direção do Egito, vê todos os prodígios que meto em tuas mãos e os farás diante do Faraó, mas eu farei resistente o coração dele e não deixará ir o meu povo".

Após a experiência no Horeb, YHWH se comunica livremente com Moisés, que passa a ser conduzido por Ele na sua missão. Moisés regressa ao Egito, este é o seu destino e seu objetivo, como porta-voz

José e Maria, para salvar o menino Jesus do "faraó" Herodes, que decretou de morte todos os meninos (Mt 2,13-23) fizeram um caminho contrário e foram na direção do Egito. Mateus usará o episódio para declarar que se cumpriu a profecia de Os 11,1: "Do Egito chamei meu filho". Com isso, a dinâmica do êxodo figura, igualmente, na vida do Messias, isto é, o novo Moisés. 
de YHWH e realizador de seus prodígios. ${ }^{8}$ Está em suas mãos a capacidade de operá-los não somente para mostrar as suas credenciais aos anciãos e ao povo a ser libertado, mas, principalmente, diante do Faraó, para lhe demonstrar com quem está o verdadeiro poder. ${ }^{9}$ Isto não significa que Moisés possui condições para causar impressão frente ao Faraó, mas que recebeu as credenciais de YHWH, isto é, a autoridade de fazer coisas que o Faraó conseguirá fazer somente através dos seus sábios, encantadores e magos (Ex 7,8-13).

Os prodígios que Moisés pode realizar têm a sua origem em YHWH. Entretanto, Moisés, por primeiro, é quem deve ver os prodígios, antes de realizá-los diante do Faraó. É por Moisés que YHWH se faz conhecido ao Faraó e, por ele, a todo o Egito. Assim como YHWH coordena as ações de Moisés, também age no íntimo e na sede das decisões do Faraó. YHWH, ao mesmo tempo em que dificulta a missão de Moisés, obstinando o coração do Faraó, demonstra a sua força frente ao que lhe põe resistência.

Está nas mãos de YHWH tanto o agir de Moisés como a resistência do Faraó. ${ }^{10}$ A falta de alusão a uma possível mudança na sentença de YHWH ou na conduta do Faraó chama a atenção do ouvinte-leitor. Essa ausência pode ser interpretada como um sinal de que, de fato, a obstinação do Faraó o impediu de ver a importância da ordem de YHWH e de reconhecer o direito dos filhos de Israel. A relutância humana não foi capaz de vencer a decisão divina de reivindicar o que lhe pertence.

\footnotetext{
Devido à mudança terminológica, há quem identifique esses prodígios com as pragas e não com os sinais realizados em Ex 4,2-9 (SCHARBERT, 2001, p. 36).

10 O tema da resistência do Faraó retornará várias vezes na narrativa das pragas. A obstinação é devida a YHWH (Ex 4,21; 7,3; 9,12; 10,1.20.27; 11,10; 14,17), mas, também, ao próprio Faraó (Ex 7,13.14.22; 8,11.15.28; 9,7.35). A razão, para essa aparente "contradição", deve-se, provavelmente, às diferentes tradições sobre o fato. A que atribui a obstinação a YHWH tem fundamentos teológicos e a que atribui ao Faraó tem fundamentos antropológicos. O autor bíblico, no primeiro caso, não se posiciona do ponto de vista da consciência humana, incapaz de prever, antecipadamente, as atitudes que decidirá tomar, mas as atribuiu a YHWH (AUZOU, 2008, p. 132).
} 
YHWH, contudo, não estava apenas dificultando a missão, mas assegurando para Moisés que Ele é o único que possui o controle da situação que fez dele o seu mediador. Moisés, tornando-se sabedor, de forma antecipada, dos obstáculos que encontraria no Egito, passou a entender, igualmente, que YHWH é “obstinado” pela libertação do seu povo. É como em uma batalha, quanto mais difícil, maior a glória da vitória.

A ordem de YHWH serve, por um lado, para assegurar que Moisés não titubearia na sua missão, mas, por outro lado, revela que ele não deveria pautá-la nos prodígios que poderia realizar. 0 êxito a ser alcançado, desde o início do regresso ao Egito, resulta da obediência que Moisés foi chamado a demonstrar. A saída do povo de YHWH, pelo texto, há de ser o fruto do rebaixamento do poderio do Faraó. Cria-se, com isso, uma identificação: a missão de Moisés consiste no projeto de YHWH. Esta identificação foi formulada como previsão dos acontecimentos futuros, pelos quais a punição que haveria de recair sobre o Faraó e sobre o Egito foi anunciada de forma profética. Moisés, ao partir, já levava consigo o desfecho da sua missão, pois, por meio dela, a justiça de YHWH tornou-se resposta ao clamor dos filhos de Israel.

$4{ }^{22} E$ dirás ao Faraó: Assim disse YHWH: o meu filho primogênito é Israel.

Não obstante a revelação da resistência do Faraó frente à exigência de YHWH, Moisés aparece, além de realizador de prodígios, como portador de uma palavra a ser dirigida ao Faraó. Isso não coaduna, por um lado, com a sua declarada incapacidade de falar (Ex 4,10-12), mas denota, por outro lado, a incapacidade que o Faraó tem para ouvir a voz que apela por justiça, isto é, para obedecer à ordem de YHWH.

Além disso, esperava-se que o oráculo fosse direcionado para os lábios de Aarão, porta-voz de Moisés diante do Faraó, conforme a solução prévia de YHWH para o problema da loquacidade de Moisés 
(Ex 4,13-16). Em contrapartida, a missão é de Moisés e é por ele que YHWH fala e revela os seus desígnios.

O conteúdo da fala, em tom de ameaça, denota a natureza da relação em forma de litígio de YHWH contra o Faraó. Assim como o Faraó é pai e tem o seu primogênito, YHWH também é pai de Israel que é o seu primogênito. YHWH reclama o direito do seu primogênito sobre o primogênito do Faraó. O que o ouvinte-leitor ainda não sabe, é que o primogênito do Faraó representa todos os primogênitos do Egito e que a obstinação de um só acarretou a sentença para muitos (Ex 11,1.4-5).

Antecipa-se, no presente da narrativa (prolepse), o futuro da ação divina. Sim, da ação divina, pois em todos os encontros, Moisés nunca dirigiu ao Faraó essa informação. Não pode passar despercebido que a fala de YHWH a Moisés, antecipando um feito, representa a expressão da justiça diante do direito paterno e do uso do seu poder a favor da própria progênie (CHILDS, 2003, 1332).

Esta é a primeira vez na Bíblia hebraica que tal declaração é feita e não se repetirá da mesma forma. 0 antigo Israel, sem essa revelação, não conceberia a ideia de um Deus-Pai. Moisés, que também é pai, carrega consigo essa revelação e, por ela, não desistirá da missão. Ao lado disso, porém, não se pode esquecer que se os filhos de Israel são para YHWH o seu primogênito, isso não significa que YHWH não considere outros povos como filhos. YHWH reclama para si o seu primogênito a quem não é o seu pai, isto é, o Faraó. Dessa reclamação resulta que YHWH tem o direito sobre todos os primogênitos nascidos dos filhos de Israel e dos animais que lhe pertencem (Ex 13,1-2). Por essa reclamação, compreende-se melhor a exigência de Abraão sacrificar a sua paternidade (Gn 22), pois Isaac é a prova de que YHWH cumpre as suas promessas.

Tal declaração lança os fundamentos para a compreensão de que Israel é o primogênito também na ordem da salvação, pela qual a promessa feita a Abraão (Gn 12,1-3) ganha corpo e sentido 
na história do antigo Israel. ${ }^{11}$ Jr 31,9 afirma que YHWH é pai para Israel, mas Efraim é o seu primogênito. ${ }^{12}$ Não estaria aqui um forte indício sobre a identificação dos que, de fato, teriam deixado o Egito?

Nessa relação de litígio, o querer e o agir do ser humano embate-se com o querer e o agir de YHWH. O comportamento previsto do Faraó teve a sua origem na decisão de YHWH, pois foi Ele quem dotou o ser humano dos sentidos (Ex 4,11). Por isso, só YHWH é capaz de prever, antecipadamente para Moisés, as dificuldades da missão, falando como o Faraó reagirá diante do: “deixa ir o meu filho”.

A força desse conteúdo lança as bases para a herança e o futuro do povo na terra prometida, mas, também, recapitula a dádiva divina feita a Abraão quando Sara teve o seu primogênito Isaac. Recapitula, igualmente, a soberania de YHWH sobre Jacó, pois lhe mudou o nome para Israel (Gn 32,29). O que Jacó não teve, quanto à revelação do nome divino (Gn 32,30), Moisés o teve em função da sua missão libertadora.

$4{ }^{23}$ Por isso te disse: deixa ir o meu filho que me servirá; mas recusastes deixá-lo ir. Eis que farei perecer teu filho, o teu primogênito."

A Septuaginta, ao invés de "meu filho" (Ex 9,35; 10,20; 11,10), traz "meu povo", pois é mais recorrente (Ex 5,1; 7,16.26; 8,16; 9,1.13; 10,3). Com isso, a versão grega pretendeu harmonizar o texto a partir do contexto subsequente. A Vulgata, porém, serve para apoiar a lição contida no Texto Massorético.

Neste versículo, percebe-se a ligação entre a notícia do risco de morte que recai sobre Moisés, por decisão do Faraó (Ex 2,15) e a notícia da morte de quem procurou tirar a sua vida (Ex 4,19). 0 intervalo entre as duas notícias, da fuga e do regresso ao Egito, é de quarenta anos. A novidade desse tempo foi a descoberta de YHWH e

11 AUZOU, G., Dalla servitù al servizio. Il libro dell'Esodo. Bologna: EDB, 2008, p. 132.

12 A imagem da paternidade aparece nos escritos proféticos, de modo particular nos textos que aludem à dor e ao sofrimento (cf. Jr 3,19; 31,20; Os 11,1-9). YHWH é um pai que se envolve com o sofrimento do seu filho primogênito e, por isso, reclama por sua vida e exige, custe o que custar, a sua liberdade (FRETHEIN, 2004, p. 105). 
do seu plano salvífico. O que se passou com Moisés torna-se o futuro para os filhos de Israel. Isso prepara o que está para ser narrado em Ex 4,24-26.

A recusa do Faraó em obedecer a Moisés, por motivo de quem ele é embaixador, pois foi constituído um mediador autorizado, denota a íntima relação que pode ser estabelecida entre profecia e lei. Para o Faraó, Moisés não é um legislador, mas se apresenta como porta-voz de YHWH, que é o único e verdadeiro legislador. Enquanto porta-voz de YHWH, Moisés representa a autoridade de quem tem nas mãos o poder sobre a vida e a morte. Moisés é quem interpreta o sentido do que foi comunicado ao Faraó. YHWH é quem decide o que acontecerá ao Faraó e à sua casa. Moisés é apenas o seu porta-voz, mas é também a ocasião para que o pior não aconteça ao Egito. O que o Faraó não fez com os filhos de Israel, YHWH está fazendo com ele, isto é, dando-lhe a chance de evitar a desgraça.

A declaração da primogenitude cria o contraste entre o que Israel tem sido para o Faraó e o que ele representa para YHWH. Fica em contraste, igualmente, a identidade do Faraó e a identidade de YHWH. Este é o pai que liberta daquele que não é pai, mas opressor. Israel, para tomar consciência da sua identidade e saber o que representa para YHWH, precisou fazer experiência da ação libertadora em conflito com a ação opressora do Faraó. Do resultado desse confronto, teve início a tradição da eleição e da filiação divina. ${ }^{13} \mathrm{O}$ sentido do verbo "servir" não muda, mas a mudança de "dono" é o que, verdadeiramente, importa. Declara-se que "servir" a Faraó é uma opressão, ao passo que "servir” a YHWH é libertação.

A ameaça pessoal de YHWH antecipa o seu último feito portentoso (Ex 11,5; 12,12.29), que imergiu o Faraó em uma profunda consternação e o obrigou a deixar partir os filhos de Israel do Egito (Ex 12,29-34). O feito anunciado causa um profundo impacto no

13 GARCíA LÓPEZ, F., Éxodo. Bilbao: Desclée De Brouwer, 2007, p. 49. 
ouvinte-leitor, que não está preparado para tal possibilidade, mas é chamado a compreender a ameaça como um ato de justiça de YHWH, pois está em conformidade com a lei do talião (NOTH, 1977, p. 59). $\mathrm{O}$ que foi feito a Israel, filho primogênito de YHWH, a matança dos primogênitos (Ex 1,16.22), provocou a paga na mesma proporção. Este mesmo feito tornou-se a base da tradição do resgate de todo primogênito macho a ser realizado após a entrada na terra de Canaã, pois a primeira cria, tanto do ser humano, como dos animais, pertence a $\mathrm{YHWH}^{14}$

A lei do talião, nessa situação, não aparece de forma proporcional, pois o não deixar partir do Faraó não é proporcional ao "farei perecer” de YHWH. Mostra-se que não houve outra forma de se quebrar a resistência do Faraó, isto é, somente com a morte do seu primogênito é que o seu coração se enfraqueceria para deixar partir, do Egito, os filhos de Israel com todos os seus pertences.

\section{Considerações finais}

O aumento de interesse pela Bíblia traz à tona antigos e novos desafios hermenêuticos: passar do nível de leitura superficial ao nível mais profundo, procurando obter não só o sentido literal, mas acima de tudo o sentido pleno de cada texto lido e estudado. Sabe-se que as escrituras sagradas do antigo Israel dão uma atenção toda particular ao tema da libertação.

O êxodo do Egito, sem dúvida, é máximo paradigma dessa temática que, de tempos em tempos, aflora na literatura e principalmente nas pregações e ações sócio-pastorais. Libertar-se do "faraó” é o desejo de todo "oprimido" em qualquer época e lugar. Contudo, o uso que se faz dos textos bíblicos, no caso específico da temática

14 Cf. Ex 13,11-16; 22,28; 34,20; Lv 26,27; Nm 3,13; 8,17; 18,15-17. Os 11,1 afirma que Israel é o filho amado de YHWH, mas por sua infidelidade tornou-se digno de ser castigado. A lembrança do êxodo ganha um novo sentido, pois ao invés de evocar a dinâmica do fato, "fiz sair do Egito", evoca a dinâmica da palavra "do Egito chamei meu filho”. É a palavra profética que interpreta o fato (SPREAFICO, 1998, 28-30). 
da libertação da opressão, muitas das vezes é impregnado de oportunismo e pode constituir, mais do que em um erro teológico, em um grave erro antropológico.

Por um lado, não é fácil apresentar, deslocada do seu contexto, essa passagem ao ser humano contemporâneo e crítico, seja crente ou não crente, mas que tem, à flor da pele, a repulsa por qualquer forma de injustiça. Por outro lado, a força da lei do talião, apesar de "antiga e ultrapassada", ainda reside no íntimo de muitos, em particular dos que se sentem lesados nos seus direitos mais básicos e fundamentais. Não é difícil, então, que alguém faça subir a Deus, ou a quem julga capaz, um clamor como o que se encontra narrado em Ex 4,19-23, na espera que se determine um basta para as injustiças, eliminando os seus agentes causadores.

$\mathrm{Na}$ ação sociopastoral, deve sobressair, muito mais, o aspecto dialógico de Deus com o seu eleito, razão pela qual demonstra todo o seu interesse por quem está sofrendo com as injustiças. Sobressai, igualmente, a firme decisão do eleito de tomar sobre si, com empenho, a missão, sabedor de que enfrentará inúmeras dificuldades, sejam elas internas ou externas.

Na vontade de Deus está a decisão pela libertação dos seus filhos e filhas, mas nas mãos do eleito está o “bastão de Deus”, isto é, o compromisso com a missão. Por este, o eleito pode até se sentir fraco, mas não esmorecerá. O eleito, por primeiro, deve estar convencido dos prodígios que deve realizar diante de todo poder opressor, seja ele civil ou religioso, pois o Faraó era representante dos dois poderes.

O futuro de uma pessoa ou povo oprimido necessita contar com agentes libertadores a exemplo de Moisés. As expectativas de sucesso do eleito, porém, ficam subordinadas à obediência à voz de Deus, que é o único capaz de dar a vida ou decretar a morte. Impede-se, categoricamente, o querer fazer justiça com as próprias mãos. É preciso ajudar a perceber que no anúncio de morte do primogênito está contida a revelação de que as injustiças cometidas, 
por quem estiver no poder, serão abatidas e não continuarão no seu descendente. Não é difícil sentir ecoar, neste sentido, a célebre frase do Magnificat: "Faz proezas com seu braço, dispersa os soberbos no pensamento do seu coração; derruba dos tronos os poderosos e eleva os humildes" (Lc 1,51-52).

Enfim, a missão do eleito envolve toda a sua família. Sem ela, a vida dos demais e suas agruras não recebem a devida atenção. Contar com a presença e o apoio da família é de fundamental importância para o eleito, mesmo sabedor de que os perigos se tornam maiores. A fé do eleito, porém, não invalida a prudência, antes a exige como condição prévia para cada passo a ser dado na direção da realização da missão. Para pensar no bem dos outros é preciso não abrir mão do bem que a própria família representa.

\section{Bibliografia}

AUZOU, G., Dalla servitù al servizio. Il libro dell'Esodo. Bologna: EDB, 2008.

CHILDS, B. S., El Libro del Éxodo. Comentario crítico y teológico. Estella: Verbo Divino, 2003.

COATS, G. W., Exodus 1-18 [vol. IIA]. Michigan/Cambridge: Grand Rapids, 1999.

DOZEMAN, T. B., Commentary on Exodus. Michigan: Grand Rapids, 2009.

FERNANDES, L. A. - GRENZER, M., Exxodo 15,22-18,27. São Paulo: Paulinas, 2011.

FRETHEIM, T. E., Esodo. Torino: Claudiana, 2004.

GARCÍA LÓPEZ, F., Éxodo. Bilbao: Desclée De Brouwer, 2007.

NEPI, A., Esodo [capitoli 1-15]. Introduzione e commento. Padova: Messaggero, 2002.

NOTH, M., Esodo. Brescia: Paideia, 1977.

RAVASI, G., Esodo. Brescia: Queriniana, 2007.

SCHARBERT, J., Esodo. Milano: Morceliana, 2001. 
SICRE, J. L., Josue. Estella (Navarra): Verbo Divino, 2002.

SILVA, L. H. E., “O Sentido Teológico do Texto Bíblico: releitura e horizontes da intervenção de Bento XVI durante o Sínodo sobre a Palavra na Vida e na Missão da Igreja”. In: Horizonte Teológico, v. 10, n. 18 (jul./ dez. 2010) pp. 9-27.

SPREAFICO, A., “Esodo: Memória e Promessa”. In: Parole di Vita 2 (1998) pp. 27-33.

Recebido em: 14/12/2015

Aprovado em: 21/04/2016 